- the death rate of the leaves during the whole growing season

- translocation and conversion of constituents at the end of grain filling

- crop photosynthesis measurements

- more detailed simulation of the development stage

- testing and improvement of the model with experiments under different conditions.

Acknowledgements. Thanks are due to the RIJP, Prof. G. J. Vervelde and Mrs H. H. van Laar.

\title{
References
}

Habekotte, A., 1978. Schaal voor de morfologische ontwikkeling (groeistadia) van winterkoolzaad. Lelystad, RIJP-rapport, $15 \mathrm{pp}$.

Louwerse, W. \& J. L. P. van Oorschot, 1969. An assembly for routine measurements of photosynthesis, respiration and transpiration of intact plants under controlled conditions. Photosynthetica 3: 305-315.

Penning de Vries, F. W. T. \& H. H. van Laar, 1982. Simulation of plant growth and crop production. Simulation Monographs. Pudoc, Wageningen, $308 \mathrm{pp}$.

This synopsis is based on an $M$. Sc. thesis entitled 'Simulatie van het produktiepatroon van koolzaad aan de hand van een veldproef bij de Rijksdienst IJsselmeerpolders te Lelystad', Department of Theoretical Production Ecology, Agricultural University, Wageningen, 1984.116 pp., 42 figs., 7 refs., 4 appendices. Dutch.

Available as paper copy (order R020P, $f 30$ including postage) or microfiches (order R020M, f 17.50 including postage) at: NARD, clo Pudoc, P.O. Box 4, 6700 AA Wageningen, Netherlands (telex 45015 blhwg $n l$ ).

\section{The influence of the phosphorus concentration in the diet on the performance of fast-growing pigs}

A. W. Jongbloed (Institute of Livestock Feeding and Nutrition Research, P.O. Box 160, 8200 AD Lelystad, Netherlands)

Accepted: 22 August 1984

Abstract. The effect of different $\mathrm{P}$ concentrations in cereal- and byproduct-based diets on performance was studied in growing pigs from 30 to $110 \mathrm{~kg}$ live weight. An 
addition of $0.75 \mathrm{~g}$ inorganic phosphorus to diets with $1.6-1.8 \mathrm{~g}$ digestible $\mathrm{P} / \mathrm{kg} \mathrm{dm}$ was sufficient to achieve optimal results.

Key-words: phosphorus, pig, digestibility, feeding trials

Introduction. Recently there was a renewed interest in the phosphorus requirements of growing pigs. In the past years there were several changes in pig husbandry, which underlie this renewed interest: the increased growth rate and better feed conversion ratio of the pigs; a change in the feedstuff composition of mixed feeds for pigs; the high price of phosphate as a feedstuff; the aspect of environmental pollution by phosphorus and a possible relationship between a shortage of phosphorus in the diet and $\mathrm{kg}$ weakness.

Material and methods. In 6 feeding experiments with in total 359 pigs (modern, fastgrowing boars and gilts; mostly crossbred) from 30 to $110 \mathrm{~kg}$ live weight the effect of the $\mathrm{P}$ concentration in the diet on the performance and leg score was investigated. In each experiment the different levels of phosphorus were realized by adding $\mathrm{CaHPO}_{4}$ to the diet in 3 or 4 steps of $0.75 \mathrm{~g} \mathrm{P}$ per kg. All diets had a Ca/P ratio of \pm 1.3:1. There were, depending on the experiment, 10 to 22 animals per treatment.

In four experiments in some treatments the $\mathrm{P}$ concentration was changed in the course of the experiment.

In four experiments the pigs were fed ad libitum; in two of these experiments a byproduct-based diet was fed. In two other experiments the pigs were fed at a high level but restrictedly; in one a predominantly cereal-based and in the other a byproduct-based diet was used.

The diets were formulated to have a $\mathrm{NE}_{\mathrm{f}}$ (net energy for fattening pigs, Dutch system) and lysine concentration of at least $9.05 \mathrm{MJ}$ and $8.5 \mathrm{~g}$ per $\mathrm{kg}$ respectively. All diets were pelleted and the water supply was ad libitum. All animals were fed individually; they were also housed individually in 5 of the 6 experiments. The live weight and in most cases the feed intake were registered weekly or biweekly. The growth rate and feed conversion ratio from 30 to $110 \mathrm{~kg}$ were calculated by means of growth and feed intake curves, which were based on orthogonal polynomia. The digestibility of several components and of phosphorus was measured in the diets without supplementation of $\mathrm{CaHPO}_{4}$. The results were analysed by analysis of variance.

Results. It appeared from the concomitant digestibility trials that the concentration of digestible $\mathrm{P}$ in the cereal- and byproduct-based diets without any $\mathrm{P}$ supplementation was almost the same: $1.6-1.8 \mathrm{~g} / \mathrm{kg} \mathrm{dm}$. Thus concerning digestible phosphorus concentration both types of diets could be compared well with each other. According to the digestibility of crude protein, crude fat, crude fibre and nitrogen free extractives it was calculated that the mean $\mathrm{NE}_{\mathrm{f}}$ concentration in the diets was 10.0 $\mathrm{MJ} / \mathrm{kg} \mathrm{dm}$

From 30 to $110 \mathrm{~kg}$ live weight the mean growth rate (of the pigs in all treatments over all experiments) was $850 \mathrm{~g} /$ day, the feed conversion ratio $25.39 \mathrm{MJ} \mathrm{NE}_{\mathrm{f}} / \mathrm{kg}$ live weight gain and the feed intake $2.47 \mathrm{~kg} /$ day. Within an experiment there were no 
statistically significant differences as a result of the different $P$ concentrations in the diet and no interactions between. sex of the animal and the P concentration in the diet. However there was a tendency that animals in the treatment without any inorganic $P$ supplementation had a somewhat lower feed intake and growth rate than animals which got diets to which $0.75 \mathrm{~g}$ inorganic $\mathrm{P}$ or more per $\mathrm{kg}$ was added. There was no effect of the $\mathrm{P}$ concentration in the diet on slaughter quality and on score of the legs.

Discussion. It is assumed that for the diet without any $\mathrm{P}$ supplementation the digestible $\mathbf{P}$ is equal to available $\mathrm{P}$. Furthermore it is assumed that the availability of the added inorganic $\mathrm{P}$ is $90 \%$. Based on these assumptions and on the results of the feeding experiments, while taking into account (for safety reasons) the tendency towards lower feed intake on the diets without any $P$ supplementation, a concentration of $2.2 \mathrm{~g}$ available $\mathrm{P}$ per $\mathrm{kg}$ diet with a $\mathrm{NE}_{\mathrm{f}}$ concentration of $8.79 \mathrm{MJ}$ for growing pigs from $30 \mathrm{~kg}$ live weight onwards is recommended. More research is needed regarding the availability of phosphorus of several separate feedstuffs for pigs.

\section{References}

Kempen, G. J. M., P. van der Kerk \& A. H. M. Grimbergen, 1976. The influence of the phosphorus and calcium content of feeds on growth, feed conversion and slaughter quality, and on the chemical, mechanical and histological parameters of the bone tissue of pigs. Netherlands Journal of Agricultural Science 24: 120-139.

Petersen, U. \& H. Vemmer, 1981. Untersuchungen zur optimalen Phosphorergänzung von Getreiderationen für wachensende Schweinen bei ad-libitum Fütterung. Landwirtschaftliche Forschung 34: 145153.

Stockland, W. L. \& L. G. Blaylock, 1973. Influence of dietary calcium and phosphorus levels on the performance and bone characteristics of growing finishing swine. Journal of Animal Science, 37: 906-912.

This synopsis is based on a report entitled 'De invloed van het fosforgehalte in het voer op de mestresultaten bij snelgroeiende varkens', Report 154, Institute for Livestock Feeding and Nutrition Research (IVVO), Lelystad, Netherlands, 1983. 35 pp., 11 tables, 10 refs. Dutch, English summary and table captions and headings.

Available as paper copy (order R021, f 12.50 including postage) or microfiche (order R021M, f 12.50 including postage) at: NARD, clo Pudoc, P.O. Box 4, 6700 AA Wageningen, Netherlands (telex 45015 blhwg $\mathrm{nl}$ ). 